\title{
Constructivism Based Blended Learning in Higher Education
}

\author{
http://dx.doi.org/10.3991/ijet.v7i1.1792 \\ Ahmad M. Al-Huneidi and Jeanne Schreurs \\ Hasselt University, Hasselt, Belgium
}

\begin{abstract}
This paper explain how to apply Constructivism and Conversation theories in Blended Learning environment in order to increase learning outcomes and quality. Some scenarios of Constructivism based blended learning activities are presented in this paper. In addition, a Constructivism Based Blended Learning model for "ICT Management" course, a compulsory course in Master of Management Information Systems program at Hasselt University, is proposed. The proposed model applies and combines Constructivism and Conversation theories in Blended Learning environment, in which the student is an active maker of knowledge. In the proposed model a variety of learning activities and scenarios, differentiated for working students and regular students are applied, supported by innovative ICT tools, which facilitate applying Constructivism and Conversation theories and increase the level of communication and interaction between students, as a result, learning quality, experience and outcomes are increased effectively.
\end{abstract}

Index Terms-Blended Learning, E-Learning, Constructivism Learning, Higher Education.

\section{INTRODUCTION}

Face-to-face learning has some advantages such as learning in a social interaction environment, which facilitate an exchange of ideas, and lower the possibility of misunderstanding. However face-to-face learning allows very limited room for self-directed learning and student-centered learning, limits the possibilities for customizing the course content to reflect learners' skills [1].

The experience gained from first generation elearning, often riddled with long sequences of 'pageturner' content and pointed-click quizzes, is giving rise to the realization that a single mode of instructional delivery may not provide sufficient choices, engagement, social contact, relevance, and context needed to facilitate successful learning and performance [2]. Although of the advantages gained from e-learning, such as possibility of learning at anytime and from anywhere, which reduced the cost, faster learning delivery, and servicing unlimited number of learners, there are a few disadvantages of e-learning, which include low motivation to complete courses, lower learner satisfaction, lack interaction with teachers and peers, difficult to use real tools, and high initial costs for developing courses [1].

Blended Learning arose to overcome the disadvantages of traditional learning and to obviate the failure of e-learning by providing a combination of various learning strategies or models. It mixes various event-based learning activities, including face-to-face class room, live elearning, student-centered learning, and self-paced learning, which increases learning quality, social contents, and learners' interactivity. Blended Learning is an evolution of e-learning; it provides the best mix of traditional learning and e-learning.

\section{CONSTRUCTIVISM AND CONVERSATION THEORIES}

One of the harshest criticisms of Blended Learning is that it focuses on the teacher for creating the knowledge, rather than on the student [7]. To overcome this drawback, Constructivism theory may applied in Blended Learning environment, which increases students' interactivity and focuses on the student to construct new knowledge based on his/her previous experience.

Constructivism theory is based on the idea that people construct their own knowledge through their personal experience. The effectiveness of Constructivism is that it prepares students for problem solving in complex environment [3]. In Constructivism theory; students are more active in building and creating knowledge, individually and socially, based on their experiences and interpretations.

Teacher's role is essential and important in learning process. The role of the teacher in Constructivism theory is to try to understand how students interpret knowledge and to guide and help them to refine their understanding and interpretations to correct any misconception arises between students at an early stage and improve learned knowledge quality.

In addition, Conversation theory supports Constructivism theory. Conversation theory is based on discussion of the learning system. It believes that the interaction and collaboration between students and teachers play an important and essential role in learning process. It focuses on continued and ongoing interaction between students and teachers. In this sense, Conversation theory of learning fits into the constructivist framework, since the emphasis is on student as an active maker of knowledge.

\section{CONSTRUCTIVISM AND CONVERSATION THEORIES IN BLENDED LEARNING ENVIRONMENT}

In Blended Learning environment, teachers should use a variety of ICT tools such as synchronous and asynchronous learning technologies to facilitate and encourage collaboration, interaction, communication, and knowledge construction and sharing among the students.

Blended Learning environment has the characteristics to adapt, support, and facilitate applying Constructivism and Conversation theories in learning process (see Figure 1). Blended Learning environment facilitates and improves 


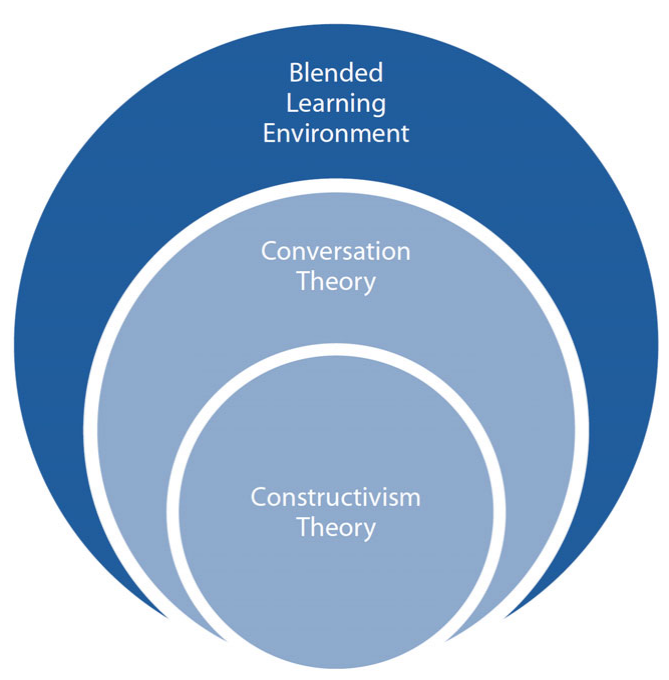

Figure 1. Adapting Conversation and Constructivism Theories in Blended Learning Environment.

discussion, communication, and knowledge construction processes as discussed later in this chapter.

Table 1 illustrates various Constructivism characteristics and their correspondent learning activities and ICT support tools to gain a better understanding of applying Constructivism characteristics in learning process.

Moreover, by applying Conversation theory beside Constructivism theory in Blended Learning environment, the students have the opportunity to interact with the teacher; in addition, the teacher has the opportunity to guide and assess students' learning and knowledge construction at an early stage and take any needed correction action if there is any misconception. Conversation theory supports Constructivism theory by facilitating collaboration, communication, interaction, and knowledge construction and sharing amongst the students, which improves learning outcomes and quality more effectively.

To apply Constructivist theory, a learning environment should be designed, implemented, and then guided through the process of collaboration and interaction between students, so that learning is constructed by the group, rather than just the individual [4].

The effectiveness of collaboration in a live or synchronous learning environment depends on dynamic and active communication between students that fosters knowledge construction and sharing [5]. Synchronous discussions are very beneficial and important for students who might not participate actively and collaboratively within face-to-face classroom. Moreover, synchronous discussions facilitate fast and efficient exchanges of ideas [6]. On the contrary, in face-to-face classroom; participation of all students in discussion process is often difficult due to time constraints or students' nervousness or shyness.

\section{CONSTRUCTIVISM BASED BLENDED LEARNING BEST PRACTICES [8], [9]}

\section{A.Knowledge Management Course Assignment}

This is a generic two part, two-week assignment on the knowledge management (KM) topic. The learning activities include both individual and collaborative activities.

Part 1: In this part each student has to visit the online university's library and search for a real-world example about a selected topic, and write a brief explanation of his/her findings. Thereafter, based on his/her previous knowledge and experience, the student has to write a 300 to 400 -word-essay regarding his/her thoughts and reactions about the topic.

Part 2: Students are formed into various teams of 3 to 5 individuals and each team will read all their colleagues' postings from part 1. Each team will choose three of their colleagues' postings that they agree to evaluate and assess.

The team will write a 400 - 500-word essay that includes:

- A brief explanation of the three postings;

- Their interpretation and understandings;

- And their thoughts, advice, and reaction.

The part 1 of this assignment begins with exploration, in which each individual has to choose a real-world example.

TABLE I.

CONSTRUCTIVISM CHARACTERISTICS AND THEIR CORRESPONDENT LEARNING ACTIVITIES AND ICT SUPPORT TOOLS.

\begin{tabular}{|c|c|c|}
\hline Constructivism Characteristics & Learning Activities & ICT support Tools \\
\hline Personalization/Customization & $\begin{array}{l}\text { Reading about a selected topic on the internet and } \\
\text { discuss it with other students and with the teacher. }\end{array}$ & $\begin{array}{l}\text { - Online chat system. } \\
\text { - Internet access. }\end{array}$ \\
\hline Responsibility & $\begin{array}{l}\text { - Conducting an interview with one of the business } \\
\text { people, followed by a presentation and discussion } \\
\text { about the interview outcomes to the whole class. } \\
\text { - Self reading followed by whole class discussion. } \\
\text { - Attending an online conference with a selected } \\
\text { business people, followed by a report requested } \\
\text { from each student about what he/she learned and an } \\
\text { online discussion. }\end{array}$ & $\begin{array}{l}\text { - Online Whiteboard system to present the } \\
\text { power point presentation to the whole class in } \\
\text { addition to the discussion. } \\
\text { - Online discussion forum. } \\
\text { - Online conference system. }\end{array}$ \\
\hline Critical Thinking & $\begin{array}{l}\text { Presenting a real life problem and asking the each } \\
\text { group of students to solve it and make a report of } \\
\text { their solution, followed by a discussion of the } \\
\text { proposed solution. }\end{array}$ & $\begin{array}{l}\text { - Online discussion forum. } \\
\text { - Online meeting system or interactive } \\
\text { whiteboard system. }\end{array}$ \\
\hline Self and Collaborative Assessment & $\begin{array}{l}\text { Group preparation of a report about selected topic, } \\
\text { followed by exchanging the reports among students } \\
\text { to assess each others' reports and then send them to } \\
\text { the teacher. }\end{array}$ & Email System. \\
\hline
\end{tabular}


In addition, knowledge construction takes place in individual contexts, in which each individual presents his/her reaction based on his/her previous knowledge. In Part 2 collaborative learning and assessment among students is promoted. Knowledge construction takes place through social negotiation, collaboration and experience. At all times, the instructor evaluates students and acts as a coach, a mentor, and/or a guide to provide his/her feedback to students and to correct any mistaken understanding that may appear between students in an early stage.

\section{B.Human Computer Interaction (HCI)Course Assignment}

This assignment is seven weeks in duration. The assignment is an HCI journal activity. It requires students to keep a human-computer interface (HCI) journal for the next six weeks and provide a summary of their report. The journal will include: Student's daily experiences and observations using devices and products with humancomputer interfaces.

The students have to write a 15 page report that includes:

- A chronological log of dates that provide a clear narrative of student observations/experiences;

- Entries that contain a description of students experience;

- And one to two pages summarizing what a student has learned from this experience and how it relates to his/her own previous knowledge.

On the first day of Week 3 each students are required to post, on the discussion board, a description of his/her experience, how usable the interface was and what changes he/she would make for improvement. Thereafter, and during the same week every student must read all classmates' postings and respond (providing reactions and/or viewpoints about the experience) to any of them. At the end of the six week period, students are required to post, on the discussion board, a summary of what they have learned and how their experiences relate to their previous knowledge.

During week 7 every student must read all classmates' postings and respond (providing reactions and/or viewpoints about the experience) to any of them and the instructor has to guide, evaluate, read all postings and provide his/her feedback.

In this Assignment students document their experiences of HCI and identify the changes that could be made to improve the interface based on their previous knowledge (Problem-solving and higher-order/critical thinking skills). In addition, active participation on the discussion board promotes and encourages collaborative learning among students and multiple perspectives. For all activities, the instructor guiding, evaluating, and providing his/her feedback on the assessment to students. Moreover, collaborative assessment takes place during week 7, in which every student must read all classmates' postings and evaluate them.

\section{Strategic Information Management Course Project}

The project is on corporate performance management (CPM) and information systems in small and medium enterprises (SME) and it takes 10 weeks in duration and includes three parts.
Part1: Theoretical concepts and methodology of CPM (Week 1-3)

Each student will visit the online university's library and search for an article that includes a real world example, then he/she will write a 700-800-word essay that contains a summary of the article's findings and student's explanation of his/her thoughts and reactions based on his/her previous experience. This assignment will be submitted at the end of Week 3 .

\section{Part 2: CPM in SME (Week 4)}

Students must read all their colleagues' postings and form questions based on their readings to be asked from a CPM expert.

The instructor will schedule an asynchronous session on the discussion board with a CPM expert within a real company to answer students' questions.

Based on colleagues' postings and the discussion between students and the CPM expert, each student will write a 500-600-word essay about his/her thoughts, reaction, and/or viewpoints. 10)

Part 3: Information System supporting CPM (Week 5-

Students will participate in a demonstration session that includes a real-world best practice CPM in a real company. This will be scheduled by the instructor. The instructor will then schedule an asynchronous Q\&A session with an expert within the company to further explore and examine the CPM within the company. Based on the acquired experience, students will develop a set of quality criteria that can be used in the selection process of CPM using a balanced scorecard (BSC).

This example starts with exploration, in which students search for a real-world example. The activities are both individual and collaborative, in which a high level of interaction takes place among students, expert consultants and the professor.

Knowledge construction takes place in individual contexts and through social negotiation, collaboration and experience. At all times instructor guides, provides feedback to students and assesses their learning (Facilitator's assessment).

\section{Programming Assignment}

This assignment is 3 weeks in duration. The class will be divided into small teams of three to five students, in which individuals on each team will search the Internet for a simple mortgage calculator and share a description of the calculator on the team's assigned discussion board. Then, as a group, the team will create a Java program with functionality similar to what was found in the calculator on the Internet. This assignment includes three parts:

In part 1 each student has to use the Internet to find a Web site that includes a mortgage payment calculator, run the calculator with a set of realistic values, and post the following on his/her team's discussion board: A link to the calculator, a description of the values that he/she input, and a description of the value(s) that the calculator generated.

In part 2 each group of students has to create a Java program that is a mortgage calculator. All codes and discussion should be posted on the discussion board. In this part, it is expected that every individual will 
contribute to this program and its discussion. The team's last entry in the discussion board should be the complete program. In part 3 the project is completed and each student will submit the following paragraphs:

- A reflection on the benefits and obstacles to programming in a team environment.

- Comment on how well he/she contributed to the programming process.

- A reflection on what he/she would have done differently if he/she could do this assignment again as a team (200 to 300 words).

\section{APPlying CONSTRUCTIVISM BASED Blended LEARNING TO "ICT MANAGEMENT" COURSE AT HASSELT UNIVERSITY}

"Information and Communication Technology (ICT) Management" is a compulsory course in Master of Management Information Systems program at Hasselt University. Part of the course description is as follows: "ICT management is responsible for ICT project management including the development and implementation of ICT solutions for the company. ICT management is organizing the ICT services enterprise-wide, supporting the business processes and the management decision making".

By applying Constructivism Based Blended Learning to "ICT Management" course, the lecture component will evolve from a fairly traditional teacher-centered learning to a much more interactive student-centered learning, in which Blended Learning environment and ICT tools will be utilized to facilitate and adapt Constructivism and Conversation theories in learning process.

The proposed Constructivism Blended Learning model consists of a variety of face-to-face classrooms and online learning activities. The learning process starts with a face to face lecture to give an overview of the course, discuss the most significant knowledge that will be taught, and learning strategies and tools that will be used. In this model a variety of online and face-to-face learning activities are differentiated for working students and regular students, in which Constructivism and Conversational theories are applied. These activities include collaboration, communication, and interactions between students themselves, the teacher, and the business people. In the last week of the course, the students attend a faceto-face class to make a written open book exam. Moreover, permanent email system is provided during the semester, in which the students can communicate with the teacher and expect response within 24 hours.

ICT support tools such as synchronous chat system, online conference system, online interactive whiteboard, and discussion forum play a significant role in learning process by facilitating communication, collaboration, interaction, and knowledge construction among the students.

The evaluation method used in this model, is a combination of online assessment and traditional assessment (written exam and project work). The teacher evaluates students' interactivities, participation, and their works in the online activities. In addition, at the last week the teacher evaluate the students based on their projects and their results in the written exam.

The main benefit of this model is that it takes into consideration working students in designing and implementing learning activities. Therefore it could be applied for both working students and regular students. Figure 2 illustrates the proposed Constructivism Based Blended Learning Model for ICT Management course.

The proposed learning process consists of 7 main phases, in which various scenarios could be applied, as illustrated in Table II. During these phases the students are building up and constructing the knowledge through a variety of learning activities linked with a continuous evaluation process.

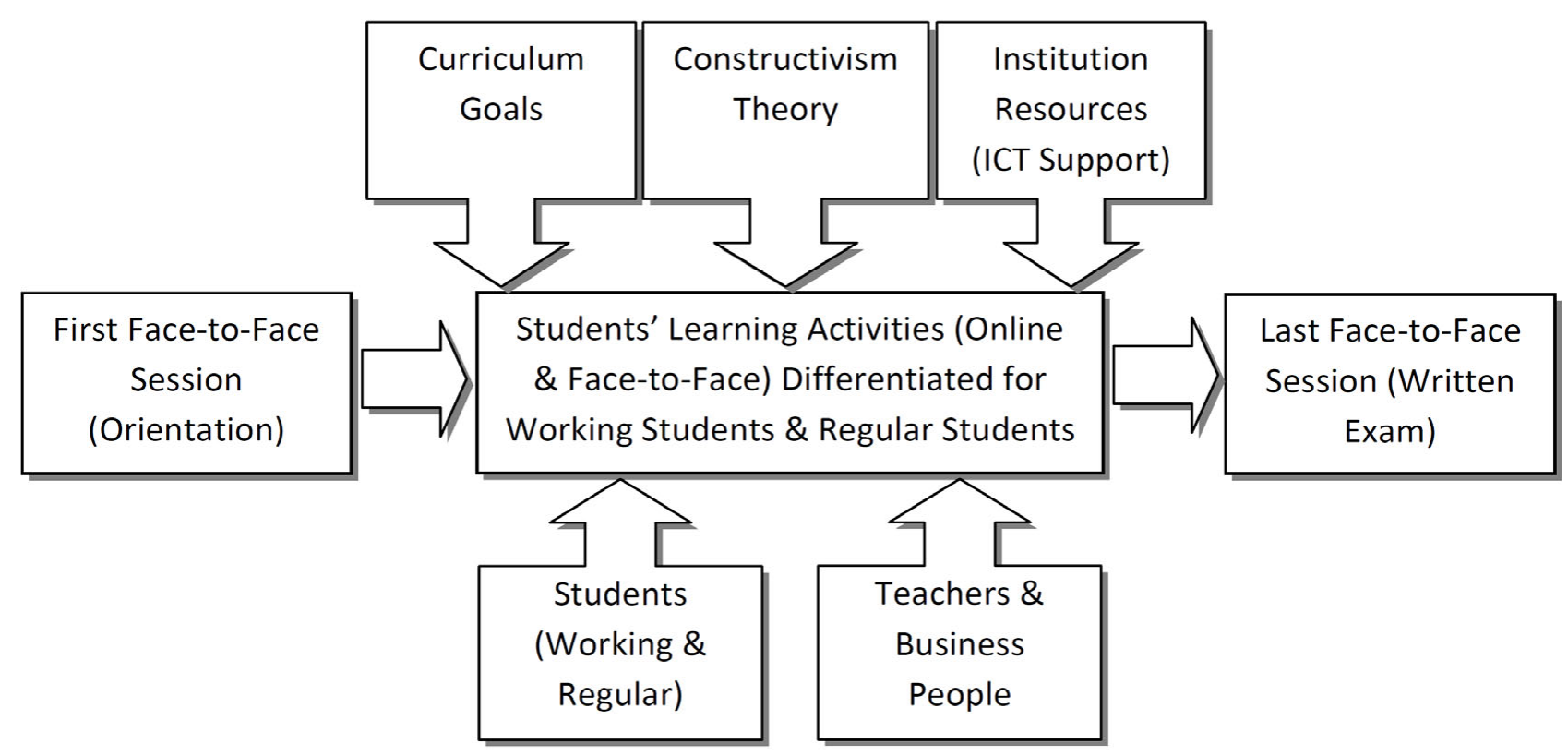

Figure 2. Constructivism Based Blended Learning Model. 
REGULAR PAPER

CONSTRUCTIVISM BASED BLENDED LEARNING IN Higher EDUCATION

TABLE II.

CONSTRUCTIVISM BASED BLENDED LEARNING PROCESS FOR “ICT MANAGEMENT” COURSE.

\begin{tabular}{|c|c|c|c|c|}
\hline $\begin{array}{l}\text { Phase } \\
\text { No. }\end{array}$ & Phase Description & Period & Scenarios & Main Activities \\
\hline 1. & $\begin{array}{l}\text { Presenting the } \\
\text { foundation of the theory } \\
\text { by the teacher. }\end{array}$ & One week & One scenario & $\begin{array}{l}\text { - Presenting course guidelines, and objectives. } \\
\text { - Discussing the most important knowledge to be } \\
\text { taught. }\end{array}$ \\
\hline 2. & Self-paced learning. & One week & One scenario & - Self study of course materials and presentations. \\
\hline \multirow{3}{*}{3.} & \multirow{3}{*}{$\begin{array}{l}\text { Search for additional } \\
\text { knowledge/ expanding } \\
\text { the knowledge. }\end{array}$} & \multirow{3}{*}{ Two weeks } & \multirow{3}{*}{ Three scenarios } & $\begin{array}{l}\text { A. Self reading and asynchronous online } \\
\text { discussion. }\end{array}$ \\
\hline & & & & $\begin{array}{l}\text { B. Internet search, preparing a presentation, and } \\
\text { making a discussion. }\end{array}$ \\
\hline & & & & $\begin{array}{l}\text { C. Internet search, writing a report, and collabora- } \\
\text { tive assessment. }\end{array}$ \\
\hline \multirow{2}{*}{4.} & \multirow{2}{*}{$\begin{array}{l}\text { Link with business } \\
\text { practices/ people. }\end{array}$} & \multirow{2}{*}{ Two weeks } & \multirow{2}{*}{ Two scenarios } & $\begin{array}{l}\text { A. Attending a conference presented by selected } \\
\text { business people, preparing a presentation/ } \\
\text { summary, and making a discussion about it. }\end{array}$ \\
\hline & & & & $\begin{array}{l}\text { B. Making an interview with one of the business } \\
\text { people, preparing a presentation, and making a } \\
\text { discussion about it. }\end{array}$ \\
\hline \multirow{4}{*}{5.} & \multirow{4}{*}{$\begin{array}{l}\text { Applying learned } \\
\text { knowledge. }\end{array}$} & \multirow{4}{*}{ Three weeks } & \multirow{4}{*}{ Four scenarios } & $\begin{array}{l}\text { A. Writing a report and making a video presentation } \\
\text { about it. }\end{array}$ \\
\hline & & & & $\begin{array}{l}\text { B. Making a research about the last theory or } \\
\text { technology in a selected topic, preparing a } \\
\text { presentation, and making a discussion about it. }\end{array}$ \\
\hline & & & & $\begin{array}{l}\text { C. Preparing a presentation about the challenges } \\
\text { and future trends of a selected topic and making a } \\
\text { discussion about it. }\end{array}$ \\
\hline & & & & $\begin{array}{l}\text { D. Proposing a solution for a real life problem, } \\
\text { selected by the teacher, and making a discussion } \\
\text { about the proposed solutions. }\end{array}$ \\
\hline 6. & Self-paced learning. & One week & One scenario & $\begin{array}{l}\text { Self studying, intensive communication with the } \\
\text { teacher, and preparation for the exam. }\end{array}$ \\
\hline 7. & Written exam. & One session & One scenario & Open-book written exam. \\
\hline
\end{tabular}

\section{CONCLUSION}

There are many benefits which make teachers choose Blended Learning over other learning strategies, such as extending the reach, increasing flexibility, pedagogical richness, reusable patterns (reusable contents and functionality), optimizing development cost, social interaction, and easy to revision and customization.

However, Blended Learning system tends to focus on the teacher for creating knowledge rather than on the student [7]. Therefore, there is a need to improve Blended Learning environment in order to apply student-centered learning methodology to increase learning outcomes, which has been achieved by applying Constructivism and Conversation theories.

Constructivism theory tends to focus on the student to construct new knowledge based on his/her experience, which increases and improves learning outcomes. Blended Learning environment and strategies has the characteristics to facilitate adapting and employing Constructivism theory's principles and elements in learning process, which improves students' critical thinking, analyzing, problem solving skills, knowledge construction, and collaborative working, through its variety of learning strategies and ICT support tools.

There are a variety of scenarios and best practices for applying Constructivism Based Blended Learning program in academic institutions, which some of them are stated in this thesis in order to acquire familiarity in employing them to improve learning outcomes.

In order to increase learning outcomes and improve learning quality more effectively, we employed Conversation theory beside Constructivism theory in Blended Learning environment model for "ICT Management" course, which is a compulsory course in Master of Management Information Systems program at Hasselt University. Since Conversation theory supports Constructivism theory by facilitating collaboration, communication, interaction, and knowledge construction and sharing amongst the students.

By applying Conversation theory beside Constructivism theory in Blended Learning environment, the students have the opportunity to interact with the teacher; in addition, the teacher has the opportunity to guide and assess students' learning and knowledge construction at an early stage and take any needed correction action if there is any misconception.

Furthermore, we applied a variety of innovative ICT support tools which play a significant role in Constructivism Based Blended Learning environment, since employing an effective and interactive ICT tools, such as online interactive whiteboard, chat system, online conference system, and discussion forum, in implementing and executing learning activities facilitates and increases collaboration, interaction, communication, and knowledge construction and sharing among the students, which improves learning outcomes and quality. 


\section{REGULAR PAPER \\ CONSTRUCTIVISM BASED BLENDED LEARNING IN HigHER EDUCATION}

The proposed model has many benefits and characteristics such as Self-paced learning, Constructivism based learning, collaborative assessment, independent problemsolving skills, critical thinking, collaboration, communication, interactivity, knowledge sharing, and flexibility.

Further research remains to be done on different levels and wider scope, such as designing and implementing a more customized, dynamic, and flexible learning model, and utilizing more innovative ICT tools and strategies, such as social media, in learning process. Moreover, future research should focus on primary education and how to design and implement a Constructivism Based Blended Learning model for primary levels. The new generation of students in primary levels is more familiar with ICT tools and able to learn new ICT skills more quickly, which can be employed to design and implement a Constructivism Based Blended Learning model for primary levels to increase and improve learning outcomes.

\section{REFERENCES}

[1] Mackay S., Stockport G. J. (2006). "Blended Learning, Classroom and E-Learning. The Business Review". Cambridge, 5(1), 82-88.

[2] Harvey Singh. (2003). "Building Effective Blended Learning Programs, Issue of Educational Technology". Volume 43. Number 6, Pages 51-54.
[3] Schuman, L. Perspectives on instruction. (1996). Retrieved July 05, 2010 from http://edweb.sdsu.edu/courses/edtec540/Perspec tives/Perspectives.html

[4] Alonso, Fernando; Genoveva Lopez Daniel Manrique; Jose M. Vines. (2005). "An instructional model for web-based e-learning education with a blended learning process approach". British Journal of Educational Technology, Vol. 36, No. 219.

[5] Singh, Harvey. (Nov-Dec, 2003). "Building effective blended learning programs". Educational Technology, Vol. 43, No. 6, pp51-54. Retrieved July 09, 2010 from http://www.book storead.com/framework/blended-learning.pdf

[6] Bremer, Claudia. (1998). "Design of a Group Oriented, Virtual Learning Environment". Retrieved July 09, 2010 from http://www.bremer.cx/paper1/

[7] Mike Carbonaro, Sharla King, Elizabeth Taylor, Franziska Satzinger, Fern Snart \& Jane Drummond. (2008). "Integration of e-learning technologies in an interprofessional health science course". University of Alberta, Canada.

[8] Koohang, Alex; Riley, Liz; Smith, Terry \& SCHREURS, Jeanne (2009), "E-Learning and Constructivism: From Theory to Application". Hasselt University, Belgium.

[9] Ahmad Al-Huneidi (2011), "Constructivism Based Blended Learning in Higher Education". Master thesis, Hasselt University, Belgium.

\section{AUTHORS}

Ahmad M. Al-Huneidi and Jeanne Schreurs are with Hasselt University, Hasselt, Belgium.

Received 17 August 2011. Published as resubmitted by the authors 28 February 2012. 